\title{
The Influence of Colour and Thickness of Nylon Mulch on Soil Temperature, Moisture, Percent Germination and Some Growth Parameters of Cucumber (cucumis sativus L.) Seedlings
}

\author{
Kayode Moses Babatunde ${ }^{1}$, Kabiru Alani Shittu ${ }^{2}$, Olusogo Adeyemi Adekanmbi ${ }^{3}$ \& Mukaila Adetunji Asimi ${ }^{4}$ \\ ${ }^{1}$ The Oke - Ogun Polytechnic, Department of Soil Science and Agricultural Technology, Saki, Oyo State, Nigeria \\ ${ }^{2}$ College of Agriculture, Osun State University, Osogbo, Nigeria \\ ${ }^{3}$ The Oke - Ogun Polytechnic, Department of Crop Production and Agricultural Technology, Saki, Oyo State, \\ Nigeria \\ ${ }^{4}$ The Oke - Ogun Polytechnic, Department of Agricultural and Bioenvironmental Engineering, Saki, Oyo State, \\ Nigeria \\ Correspondence: Kayode Moses Babatunde, The Oke - Ogun Polytechnic, Department of Soil Science and \\ Agricultural Technology, Saki, Oyo State, Nigeria. E-mail: mbabatundekayode@gmail.com
}

Received: April 7, 2020 Accepted: May 10, 2020 Online Published: May 15, 2020

\begin{abstract}
Heat, moisture and oxygen are important factors that has controlled seed germination, thus A $2 \times 4$ factorial greenhouse experiment was conducted to determine the influence of colour and thickness of nylon mulch on soil temperature, moisture, percent germination and selected growth indicators of cucumber (Cucumis sativus L.) seedlings in a completely randomized design (CRD), where the treatments; nylon colour (white and black) and thicknesses $(0,1.5,3.0$, and $4.5 \mathrm{~mm})$ were replicated three times. The analysis of variance showed that the white nylon thickness had positive significant $(P \leq 0.05)$ influence on soil temperature, soil moisture, plant height and number of leaves, while black nylon thickness had positive significant $(P \leq 0.05)$ influence on soil moisture and plant height and a negative significant $(P \leq 0.01)$ influence on percent germination, it was also discovered that 1.5 $\mathrm{mm}$ thickness of the white nylon contributed significantly $(\mathrm{p} \leq 0.05)$ to the parameters measured, therefore, white nylon of $1.5 \mathrm{~mm}$ thickness could be recommended as mulch material for cucumber production in a sandy clay soil.
\end{abstract}

Keywords: black, conserve, horticultural, mulching, plastic, radiation, seeds, solar, vegetable, white

\section{Introduction}

Mulching with appropriate materials has a number of effects on the soil temperature, conserves soil moisture, texture and fertility; and controls weeds, pests and diseases as reported by Hanada (1991). Bonanno and Lamont (1987), also found that transparent and black plastic films created favourable conditions for increasing temperature in soil. The added soil temperature was $4.9^{\circ} \mathrm{C}$ higher under clear plastic mulch where the air temperature is one of the most important meteorological elements determining the rate of plant growth and development. The practice of mulching has been utilised to great advantage in the development of horticultural crops and has been proven to significantly improve the growing conditions of vegetables (Smolikowski et al., 2001). Mulch technical term means covering of soil, while natural mulches such as leaves, straw, dried leaves and compost have been used for centuries and add nutrients to the soil through decomposition, but the advent of synthetic materials has altered the method and benefit of natural mulches (Bhella, 2000). Plastic mulches have been used commercially on vegetables since early 1960s to modulate the micro-climate around the plants and decreasing the soil water loss, especially black and clear plastic films on soil, air temperature, moisture retention and vegetable yields (Liakatas et al., 2003). Inorganic mulch such as black plastic mulch absorbs most incident solar radiation and it transmits and reflects very little, while transparent plastic mulch allows light to pass through and aids in weed growth (Lamont, 2007). The importance of mulching to crops is mainly to prevent loss of water by evaporation, to cut down weed growth, to reduce temperature fluctuations and to promote soil productivity (Decoteau et al, 2000).

\subsection{Justification of This Study}

The colour of mulching material largely determines its energy-radiating behaviour and its influence on the microclimate around a vegetable plant. By using different polymers and additives, it is possible for films to transmit, 
absorb or reflect different wavelengths preferentially. It is possible therefore, to create a wide variety of microclimates by using different types of film, either as covers over crops or as mulch on the soil surface (Ahmed et al., 2001). The purpose of assorted colours is to reflect far red: red ratios that result in phytochrome regulation that may enhance plant growth and yield (Franquera, 2015). Plastic mulching has been developed mainly for vegetable crops (Ibarra-jamenez et al., 2004; Lamont, 2005; Díaz-Pérez, 2010). This has made some development in coloured mulch technology which helps in the improvement of vegetable production.

Cucumber (Cucumis sativus L.) is one of the most profitable vegetable crops grown under protected cultivation systems all over the world, and it belongs to the guard family Cucurbitaceae (Ibeawuchi et al., 2008; El-Wanis et al., 2012). It is a sub-tropical vegetable crop that grows successfully under conditions of high light, high humidity, high soil moisture, temperature and fertilizers in greenhouse (El-Aidy et al., 2007). Cucumber is a typical vegetable of warm temperate and cool tropical areas.

Seed germination is a complex process and regulated by many factors such as nutrient, temperature, water, light and substrate (Shinomura et al., 1996; Nikolaeva et al., 2002). Germination of seed could be epigeal or hypogeal germination and is influenced by various environmental factors, availability of moisture and moderate degree of temperature also play vital roles in the production and quality of plants (Spears et al. 2005; Bettey and Finch 2000).

The objective of this study was to investigate the influence of colors and thickness of nylon mulch on soil temperature, moisture, percent germination and some growth parameters of cucumber (Cucumis sativus L.) seedlings.

\section{Materials and Methods}

The study was carried out at the greenhouse, Teaching and Research farm of the Soil Science and Agricultural Technology Department of The Oke-Ogun Polytechnic, Saki, located within Latitude $8.3^{\circ} \mathrm{N}$ and Longitude $2.4^{0} \mathrm{E}$ in the derived savannah zone, Oyo State, South Western Nigeria, between $11^{\text {th }}$ and $15^{\text {th }}$ of September, 2019. The pattern of rainfall is bimodal with average annual rainfall estimated to be about $1200 \mathrm{~mm}$ (The Oke-Ogun Polytechnic Watch Dog weather station, 2019). The experiment was carried out in bowls filled with 2 kilograms of sieved soil sample. The materials used for this experiment are; soil, sieve $(2 \mathrm{~mm})$, bowl, cucumber seeds (St. Naktuinbouw 21 var), polythene nylon (white and black color), micrometer caliper to measure the nylon thickness, water, watering can, paper tape, oven, 4 in 1 digital meter and measuring scale. The soil sample was taken at 15 $\mathrm{cm}$ dept from the field and air dried for 48 hours, sieved with $2 \mathrm{~mm}$ sieve into bowls weighed 2 kilograms of soil. The particle size distribution was carried out using the hydrometer method described by Bouyoucos (1962) as presented by (Gee and Or, 2002) using $0.2 \mathrm{M}$ sodium hydroxide as dispersing agent. The soil $\mathrm{pH}$ was determined using a glass electrode $\mathrm{pH}$ meter, that is; soil - water suspension (1:1); organic carbon was determined by the chromic acid digestion method (Walkley and Black, 1935). The total nitrogen concentration was determined by macro-Kjeldahl method (Bremner, 1996), and the available P was extracted by Bray -1 method (Kuo, 1996) and determined using spectrometer. Exchangeable $\mathrm{K}, \mathrm{Ca}, \mathrm{Na}$, and $\mathrm{Mg}$ were extracted with neutral ( $\mathrm{pH} 7$ ) solution of $1 \mathrm{~N} \mathrm{NH}_{4} \mathrm{OAc}, \mathrm{K}$ and $\mathrm{Na}$ were determined using the flame photometer and $\mathrm{Mg}$ and $\mathrm{Ca}$ by the atomic absorption spectrophotometer.

Completely randomized design (CRD) was used with two colors and four thicknesses and each treatment replicated three (3) times. The sieved soil area of the bowl measured $10 \mathrm{~cm}$ by $12 \mathrm{~cm}\left(120 \mathrm{~cm}^{2}\right)$ and was covered with the mulch materials of varied thicknesses of 0 (control), 1.5, 3 and $4.5 \mathrm{~mm}$ without opening to prevent the seedlings from growing beyond the covered mulch materials, being a germination experiment, but partial openings between fastened mulch materials and the experimental bowls. Farm yard manure (poultry) was applied to the bowls at $500 \mathrm{~g} / 2 \mathrm{~kg}$ soil/ bowl to serve as basal application. The soil moisture content was determined by the oven dry method, the soil temperature (the soil temperature measurement was at $5 \mathrm{~cm}$ depth from day one to five of the sown seeds at 06:00 and 18:00 hours) with the use of digital probe 4 - in one meter, the percent germination was simply counted. Growth parameters of the cucumber seedlings were measured from the bowls/pots; plant height $(\mathrm{cm})$, number of leaves and leaf area $\left(\mathrm{cm}^{2}\right)$ at the end of the experiment (5 days of germination). The tallest seedling (three (3) seeds/bowl was sown) from each bowl was selected for plant height measurement which was measured from the soil level to tip of the plant with a meter rule. The number of leaves was simply counted. Determination of leaf area Index (LA1) as described by (Watson et al., 2006).

\subsection{Statistical Analysis}

Data collected from the field were subjected to Analysis Of Variance (ANOVA) of Minitab 16 software package and Least Significant Difference (LSD) to separate the means. 


\section{Results and Discussions}

The soil used for the greenhouse experiment showed that the physical and chemical properties of the soil could be observed as conducive for seed germination (Table 1). The soil texture was sandy clay and the $\mathrm{pH}$ was within acceptable range of nutrient availability in soil and for plant uptake (Marinari et al., 2006). The soil was expected to hold enough water and oxygen for the germination of the seeds of cucumber due to the texture of the soil used. The soil temperature at germination at varied thickness of white nylon mulch indicated that, control $(0 \mathrm{~mm})$ and $\mathrm{W} 4(4.5 \mathrm{~mm})$ had the same temperature $\left(29^{\circ} \mathrm{C}\right)$ (Table 2), while $\mathrm{W} 2(1.5 \mathrm{~mm})$ and $\mathrm{W} 3(3.0 \mathrm{~mm})$ also had the same soil temperature $\left(31^{\circ} \mathrm{C}\right)$ at germination, however, (Table 2$)$ also showed that the soil temperature at germination due to the effect of varied black nylon mulch thickness had lesser soil temperature $\left(28^{\circ} \mathrm{C}-29^{\circ} \mathrm{C}\right)$ when compared with white nylon mulch $\left(29^{\circ} \mathrm{C}-31^{\circ} \mathrm{C}\right)$, this observation was supported by Katan, 1981 when he reported that black plastic temperature were lower than the clear/white plastic due to less effectiveness of black colour to transmit solar radiation, the highest soil temperature at germination $\left(31^{\circ} \mathrm{C}\right)$ was achieved at $1.5 \mathrm{~mm}$ thickness of white nylon mulch (Table 2) and $\left(29^{\circ} \mathrm{C}\right)$ at $3 \mathrm{~mm}$ thickness for black nylon (Table 2). The table of summary of analysis of variance of influence of white and black nylon mulch thickness on soil microclimate, germination and some growth parameters of cucumber seedlings (Table 8 ) indicated that the thickness of the white nylon much had significant $(\mathrm{P} \leq 0.01)$ effects on the soil temperature at germination of cucumber seeds, while thickness of black nylon mulch did not have significant $(\mathrm{P}=0.05)$ influence on the soil temperature at germination. The means separation by LSD $(\mathrm{P}=0.05)$ of the significant influence of varied thickness of white nylon mulch on the soil temperature at germination of cucumber seeds (Table 2) observed soil temperature of $31^{\circ} \mathrm{C}$ at both $1.5 \mathrm{~mm}$ and $3.0 \mathrm{~mm}$ thicknesses were statistically different from $29^{\circ} \mathrm{C}$ at 0 and $4.0 \mathrm{~mm}$ thicknesses.

Table 1. Properties of the soil (0-15 cm depth) used for the greenhouse experiment

\begin{tabular}{|c|c|c|}
\hline \multicolumn{2}{|c|}{ Properties } & Values \\
\hline \multicolumn{3}{|c|}{ 1. Particle size distribution } \\
\hline (a) & Sand (\%) & 67 \\
\hline (b) & Silt (\%) & 7 \\
\hline (c) & Clay (\%) & 26 \\
\hline \multicolumn{2}{|c|}{ Texture } & Sandy clay \\
\hline \multicolumn{3}{|l|}{ 2. Chemical } \\
\hline \multirow[t]{2}{*}{ (a) } & \multicolumn{2}{|l|}{ Soil pH } \\
\hline & Soil $\mathrm{pH}$ (1:1 water) & 6.7 \\
\hline (b) & Soil organic matter $(\%)$ & 1.3 \\
\hline (c) & Organic carbon $(\%)$ & 0.8 \\
\hline (d) & Nitrogen (\%) & 0.3 \\
\hline (e) & Phosphorous (ppm) & 0.4 \\
\hline \multirow[t]{5}{*}{ (f) } & \multicolumn{2}{|c|}{ Exchangeable cations $(\mathrm{Cmol}(+) / \mathrm{kg})$} \\
\hline & $\mathrm{Na}^{+}$ & 0.3 \\
\hline & (ii) $\mathrm{K}^{+}$ & 0.4 \\
\hline & (iii) $\quad \mathrm{Ca}^{2+}$ & 0.9 \\
\hline & (iv) $\quad \mathrm{Mg}^{2+}$ & 0.7 \\
\hline \multirow[t]{3}{*}{ (g) } & \multicolumn{2}{|c|}{ Exchangeable acidity $(\mathrm{Cmol}(+) / \mathrm{kg})$} \\
\hline & $\mathrm{H}^{+}$ & 0.1 \\
\hline & $\mathrm{Al}^{3+}$ & 0.2 \\
\hline (h) & CEC & 2.4 \\
\hline
\end{tabular}


Table 2. The influence of white (W) and black (B) nylon mulch thickness on average soil temperature $\left({ }^{\circ} \mathrm{C}\right) \quad(\mathrm{n}=$ 36)

\begin{tabular}{lllllllll}
\hline & W1 & B1 & W2 & B2 & W3 & B3 & W4 & B4 \\
\hline R1 & 29 & 29 & 30 & 28 & 31 & 29 & 29 & 29 \\
R2 & 28 & 29 & 31 & 28 & 30 & 29 & 30 & 28 \\
R3 & 29 & 29 & 31 & 29 & 31 & 29 & 29 & 28 \\
Total & 86 & 87 & 92 & 85 & 92 & 87 & 88 & 85 \\
Av & $29 \mathrm{~b}$ & $29 n s$ & $31 \mathrm{a}$ & $28 n s$ & $31 \mathrm{a}$ & $29 n s$ & $29 \mathrm{~b}$ & $28 n s$ \\
\hline
\end{tabular}

Means that do not share a letter are significantly different at $(\mathrm{P}=0.05)$

The soil moisture increased from control to W4 $(0 \mathrm{~mm} ; 5 \mathrm{~g} / \mathrm{g},-4.5 \mathrm{~mm} ; 12 \mathrm{~g} / \mathrm{g})$ in the white nylon bowls (Table $3)$, despite the increased in soil temperature, this might be due to the white nylon mulch that prevented the escape of the soil moisture in vapour form to the atmosphere. The black nylon mulch conservation of soil moisture (Table 3) followed the white nylon mulch, this was in line with the findings of Abdel- Hafeez and Abu-Goukh (1984), and however, the black nylon mulch increment of soil moisture $(5-9.3 \mathrm{~g} / \mathrm{g})$ at germination was less than white nylon mulch $(5-12 \mathrm{~g} / \mathrm{g})$. The summary of analysis of variance (Table 8$)$ observed a significant $(\mathrm{P} \leq 0.01)$ influence of white and black nylon mulch thickness on the improvement of soil moisture at germination of cucumber seeds, but the improvement in the soil moisture was more pronounced in white nylon than the black nylon mulch, this could be because the white nylon allowed more heat and increased in soil temperature (Table 2) and eventually more water to be converted into vapour and condensed. The LSD $(\mathrm{P}=0.05)$, (Table 3), revealed that the white nylon thicknesses $(0,1.5$, and $3.0 \mathrm{~mm})$ are statistically $(\mathrm{P}=0.05)$ the same and statistically $(\mathrm{P}=0.05)$ different from $4.5 \mathrm{~mm}$ thickness, while in the black nylon mulch, the thickness of 0 and $1.5 \mathrm{~mm}$ are statistically $(\mathrm{P}=0.05)$ the same and statistically $(\mathrm{P}=0.05)$ different from $3.0 \mathrm{~mm}$ and $4.5 \mathrm{~mm}$ thicknesses.

Table 3. The influence of white (W) and black (B) nylon mulch thickness on average soil moisture content (g/g) at germination $(\mathrm{n}=36)$

\begin{tabular}{lllllllll}
\hline & W1 & B1 & W2 & B2 & W3 & B3 & W4 & B4 \\
\hline R1 & 6 & 3 & 6 & 6 & 6 & 8 & 13 & 9 \\
R2 & 5 & 5 & 6 & 6 & 8 & 9 & 12 & 8 \\
R3 & 4 & 7 & 6 & 7 & 8 & 8 & 11 & 11 \\
Total & 15 & 15 & 18 & 19 & 22 & 25 & 36 & 28 \\
Av & $5 \mathrm{~b}$ & $5 b$ & $6 \mathrm{~b}$ & $6.3 b$ & $7.3 \mathrm{~b}$ & $8.3 a$ & $12 \mathrm{a}$ & $9.3 a$ \\
\hline
\end{tabular}

Means that do not share a letter are significantly different at $(\mathrm{P}=0.05)$

The thickness $(1.5 \mathrm{~mm})$ of white nylon mulch had the highest percent germination ( $85 \%)$ (Table 4$)$ and the least germination ( $59 \%$ ) of cucumber seeds was achieved at 3.0 and $4.5 \mathrm{~mm}$ thickness, this might due to a great reduction of oxygen diffusion into the soil as a result of greater thickness (3.0 and $4.5 \mathrm{~mm})$ of the white nylon mulch material. The black nylon mulch reduced the percent germination of cucumber $(78-33 \%)$ from control $(0$ - $4.5 \mathrm{~mm}$ ) thickness (Table 4). The white nylon mulch thickness had no significant $(\mathrm{P}=0.05)$ influence on the percent germination of cucumber seeds, but significant $(\mathrm{P}=0.05)$ influence of black nylon mulch thickness was recorded on the percent germination of cucumber seeds (Table 8). The LSD indicated that W4 (4.5 mm) thickness had significant $(\mathrm{P}=0.05)$ reduced influence on the germination percentage of cucumber seeds (Table 4$)$, while other thickness were statistically $(p=0.05)$ the same. 
Table 4. The influence of white (W) and black (B) nylon mulch on average percent (\%) germination $(\mathrm{n}=36)$.

\begin{tabular}{lllllllll}
\hline & W1 & B1 & W2 & B2 & W3 & B3 & W4 & B4 \\
\hline R1 & 67 & 100 & 78 & 89 & 67 & 89 & 33 & 33 \\
R2 & 100 & 100 & 78 & 50 & 55 & 50 & 78 & 33 \\
R3 & 67 & 67 & 100 & 67 & 56 & 67 & 67 & 33 \\
Total & 234 & 234 & 256 & 206 & 178 & 206 & 178 & 99 \\
Av & $78 \mathrm{~ns}$ & $78 a$ & $85 \mathrm{~ns}$ & $69 a$ & $59 \mathrm{~ns}$ & $69 a$ & $59 \mathrm{~ns}$ & $33 b$ \\
\hline
\end{tabular}

Means that do not share a letter are significantly different at $(\mathrm{p}=0.05)$

The plant height increased as a consequence of using the white and black nylon mulch materials, but the increased in height was more pronounced in black nylon $(5.7-11 \mathrm{~cm})$ than that of white nylon $(5.7-8.7 \mathrm{~cm})$ and this could be attributed to the seedlings response to phototropism which was a starvation of light as a result of black nylon mulch and elongation of the seedlings in search of light (Table 5). The significant $(\mathrm{p} \leq 0.01)$ increased influence of black nylon was more pronounced $(\mathrm{P} \leq 0.05)$ than the white nylon mulch thickness (Table 8 ). The LSD influence of white and black nylon mulch thickness on average plant height of cucumber seedlings indicated that control (0 $\mathrm{mm}$ ) thickness was statistically ( $\mathrm{P}=0.05)$ different from other thicknesses for both nylon colors ( Table 5), this observation of effects of colors of mulch materials was also observed by Franquera, 2011 on Lettuce (Lactuca sativa).

The thickness $(1.5 \mathrm{~mm})$ of the white nylon mulch (Table 6) had the highest number of leaves (4) even when compared with all black nylon mulch thicknesses (Table 6), the analysis of variance observed significant $(\mathrm{P} \leq 0.05)$ influence of white nylon mulch thickness on the number of leaves while significant $(\mathrm{P}=0.05)$ influence of black nylon thickness was not observed on the number of leaves of cucumber seedlings (Table 8) and the LSD (Table 6) indicated $1.5 \mathrm{~mm}$ thickness of white nylon mulch was statistically $(\mathrm{P}=0.05)$ different from other thicknesses of the white nylon mulch and had an increased influence on the number of leaves of cucumber seedlings, Mutetwa and Mtaita, (2014), also recorded a significant $(P=0.05)$ influence of colours of mulch materials on the number of leaves on the main branch of cucumber.

Both colours and thicknesses of the nylon mulch materials numerically increased the leaf areas of the cucumber seedlings, while W2 $(1.5 \mathrm{~mm})$ had the highest leaf area $\left(9.3 \mathrm{~cm}^{2}\right)$ for the white nylon; W4 $(4.5 \mathrm{~mm})$ had the highest leaf area $\left(9 \mathrm{~cm}^{2}\right)$ for black nylon (Table 7), however, both the color and thicknesses had no significant $(\mathrm{P}=0.05)$ influence on the leaf area of cucumber seedlings.

Table 5. The influence of white (W) and black (B) nylon mulch on average plant height $(\mathrm{cm}),(\mathrm{n}=36)$.

\begin{tabular}{lllllllll}
\hline & W1 & B1 & W2 & B2 & W3 & B3 & W4 & B4 \\
\hline R1 & 6 & 6 & 8 & 11 & 8 & 11 & 8 & 12 \\
R2 & 5 & 5 & 6 & 9 & 7 & 13 & 8 & 12 \\
R3 & 6 & 6 & 8 & 11 & 7 & 9 & 10 & 9 \\
Total & 17 & 17 & 22 & 31 & 22 & 33 & 26 & 33 \\
Av & $5.7 \mathrm{~b}$ & $5.7 b$ & $7.3 \mathrm{a}$ & $10.3 a$ & $7.3 \mathrm{a}$ & $11 a$ & $8.7 \mathrm{a}$ & $11 a$ \\
\hline
\end{tabular}

Means that do not share a letter are significantly different at $(\mathrm{p}=0.05)$

Table 6. The influence of white (W) and black (B) nylon mulch on average number of leaves $(n=36)$.

\begin{tabular}{lllllllll}
\hline & W1 & B1 & W2 & B2 & W3 & B3 & W4 & B4 \\
\hline R1 & 2 & 3 & 3 & 2 & 3 & 2 & 4 & 3 \\
R2 & 2 & 3 & 4 & 3 & 3 & 2 & 3 & 3 \\
R3 & 2 & 3 & 4 & 2 & 3 & 2 & 3 & 2 \\
Total & 6 & 9 & 11 & 7 & 9 & 6 & 10 & 8 \\
Av & $2 \mathrm{~b}$ & $3 n s$ & $4 \mathrm{a}$ & $2 n s$ & $3 \mathrm{~b}$ & $2 n s$ & $3 \mathrm{~b}$ & $3 n s$ \\
\hline
\end{tabular}

Means that do not share a letter are significantly different at $(\mathrm{P}=0.05)$ 
Table 7. The influence of white (W) and black (B) nylon mulch on average leaf area $\left(\mathrm{cm}^{2}\right)(\mathrm{n}=36)$.

\begin{tabular}{lllllllll}
\hline & W1 & B1 & W2 & B2 & W3 & B3 & W4 & B4 \\
\hline R1 & 8 & 7 & 9 & 9 & 9 & 7 & 10 & 9 \\
R2 & 7 & 8 & 10 & 8 & 8 & 8 & 8 & 9 \\
R3 & 9 & 8 & 9 & 8 & 8 & 9 & 9 & 9 \\
Total & 24 & 23 & 28 & 25 & 25 & 24 & 27 & 27 \\
Av & $8 \mathrm{~ns}$ & $7.7 n s$ & $9.3 \mathrm{~ns}$ & $8.3 n s$ & $8.3 \mathrm{~ns}$ & $8 n s$ & $9 \mathrm{~ns}$ & $9 \mathrm{9ns}$ \\
\hline
\end{tabular}

Means that do not share a letter are significantly different at $(\mathrm{p}=0.05)$

Table 8. Summary of analysis of variance of influence of colors and thickness of nylon mulch on soil temperature, moisture, percent germination and some growth parameters of cucumber (Cucumis sativus L.) seedlings

\begin{tabular}{|c|c|c|c|c|}
\hline & \multicolumn{2}{|c|}{ White nylon } & \multicolumn{2}{|c|}{ Black nylon } \\
\hline & $\mathrm{ms}$ & P-v & $\mathrm{ms}$ & P-v \\
\hline Soil temp & $1.11^{* *}$ & 0.01 & $0.44 \mathrm{~ns}$ & 0.12 \\
\hline Soil moisture & $28.75^{* *}$ & 0.01 & $11.42 *$ & 0.02 \\
\hline Germination \% & $526 \mathrm{~ns}$ & 0.21 & $973^{*}$ & 0.05 \\
\hline Plant height & $4.53^{*}$ & 0.03 & $19.89^{* *}$ & 0.01 \\
\hline Number of leaves & $0.97^{*}$ & 0.02 & $0.56 \mathrm{~ns}$ & 0.08 \\
\hline Leaf area & $1.11 \mathrm{~ns}$ & 0.25 & $0.97 \mathrm{~ns}$ & 0.15 \\
\hline
\end{tabular}

**Significant at $P \leq 0.01$

* Significant at $P \leq 0.05$

ns $=$ not Significant at $P \leq 0.05$

$\mathrm{ms}=$ mean square

$\mathrm{P}-\mathrm{v}=$ probability value

\section{Conclusion and Recommendation}

The influence of white and black nylon thickness mulch materials was investigated on a sandy clay soil in the greenhouse, the thicknesses were; $0,1.5,3.0$ and $4.5 \mathrm{~mm}$. The parameters (soil temperature, soil moisture, percent germination, plant height, number of leaves and leaf area) were measured and the results indicated the white nylon thickness $0-1.5 \mathrm{~mm}$ and $0-4.5 \mathrm{~mm}$, increased soil temperature $\left(29^{\circ} \mathrm{C}-31^{\circ} \mathrm{C}\right)$, soil moisture $(5-12 \mathrm{~g} / \mathrm{g})$, percent germination $(78-85 \%)$, plant height $(6-9 \mathrm{~cm})$, number of leaves $(2-4)$, leaf area $\left(8-9.3 \mathrm{~cm}^{2}\right)$ and the black nylon thickness $0-4.5 \mathrm{~mm}$ and $0-3.0 \mathrm{~mm}$, increased soil moisture $(5-9.3 \mathrm{~g} / \mathrm{g})$, plant height $(5.7-11 \mathrm{~cm})$ number of leaves $(2-3)$, leaf area $\left(7.7-9 \mathrm{~cm}^{2}\right)$ while $0-1.5 \mathrm{~mm}$ and $0-4.5 \mathrm{~mm}$ of black nylon reduced soil temperature $\left(29-28^{\circ} \mathrm{C}\right)$ and percent germination $(78-33 \%)$ respectively. Generally, the white nylon used as mulch materials had positive significant $(P \leq 0.05)$ influence on the soil temperature, soil moisture, plant height and number of leaves, the black nylon also had significant $(P \leq 0.05)$ on soil moisture and plant height, but negative significant $(P \leq 0.05)$ influence on the percent germination of cucumber seedlings.

It was therefore concluded, that white nylon was better as mulch material than the black nylon, and $1.5 \mathrm{~mm}$ thickness was consistent in all the significant $(P \leq 0.05)$ influence of the white nylon as mulch on all parameters (especially soil temperature, soil moisture, plant height and number of leaves) considered, thus the thickness (1.5 $\mathrm{mm}$ ) was also recommended for white nylon as mulch material.

\section{Conflict of Interests}

The authors declared that there was no conflict of interests regarding the publication of this paper.

\section{References}

Abdel-Hafeez, A. T., \& Abu-Goukh, A. A. (1984). Use of plastic mulch on cucumber (Cucumis sativus) production 
under sudan conditions. Sudan Agricultural Journal, 10, 19-27. Retrieved from http://www.sciepub.com/reference/164574.

Ahmed, M., Baiyeri, K. P., \& Echezona, B. C. (2013). Effect of colored polyethylene mulch and harvesting stage on growth and yield of industrial sugarcane in Nigeria. African Journal of Biotechnology, 12, 1078-1083. Retrieved from https://www.ajol.info/index.php/ajb/article/view/128165.

Bettey, M., \& Finch-Savage, W. E. (2000). Stress protein content of mature Brassica seeds and their germination performance. Seed Science Research, 8, 347-355. https://www.jstor.org/stable/2588727.

Bhella, H. S. (2000). Evaluation of mulches for use in home garden. Horticultural Science, 113, 543. Retrieved from https://www.google.com/search?.

Bonanno, A. R., \& Lamont, W. J. (1987). Effect of polyethylene mulches, irrigation method and row covers on soil and air temperature and yield of muskmelon. Journal of America Society, 112, 735-738. Retrieved from https://agris.fao.org/agris-search/search.do?recordID=US875707988.

Bouyoucous, G. H. (1962). Hydrometer Method Improved for Making Particle Size Analysis of Soils. Agronomy Journal, $\quad 54, \quad 464-465 . \quad$ Retrieved $\quad$ from https://www.scirp.org/(S(351jmbntvnsjt1 aadkposzje))/reference/ReferencesPapers.aspx?ReferenceID=1117 225.

Bremner, J. M. (1996). Total Nitrogen. In: Sparks, D.L., Ed., Methods of Soil Analysis, Part 3, Chemical Methods, SSSA and ASA, Madison, 1123-1184. Retrieved from https://www.scirp.org/(S(351jmbntvnsjt1 aadkposzje))/reference/ReferencesPapers.aspx?ReferenceID=1229 275 .

Decoteau, D., Kasperbauer, I., \& Hunt, P. G. (2000). Mulch surface colour affects yield of fresh market tomatoes. Journal America Horticultural Science, 114, 216-220. Retrieved from http://agris.fao.org/agrissearch/search.do?recordID=US8923047.

Díaz-Pérez, J. C. (2010). Bell pepper (Capsicum annum L.) grown on plastic film mulches: effects on crop Micro environment, physiological attributes, and fruit yield. Horticulture Science, 45, 1196-1204. Retrieved from https://www.researchgate.net/publication/235257120.

El-Aidy, F., El-Zawely, A., Hassan, N., \& El-Sawy, M. (2007). Effect of Plastic Tunnel Size on Production of Cucumber in Delta of Egypt. Apply Ecological Environmental Research, 5(2), 11-24. Retrieved from http://www.aloki.hu/pdf/0502_011024.pdf.

El-Wanis, A., Mona, M., Abdel-Baky, M. H., \& Salman S. R. (2012). Effect of grafting and salt stress on the growth, yield and quality of cucumber grown in NFT system. Journal of Applied Sciences Research, 8(10), 5059-5067. Retrieved from https://www.researchgate.net/publication/286168004.

Franquera, E. N. (2015). Leaf Morphological Characteristics of Leaf Lettuce (Lactuca sativa L.) as Affected by Different Colored Plastic Mulch. Current Agriculture Research Journal, 3(1), 20-25. http://dx.doi.org/10.12944/CARJ.3.1.04.

Franquera, E. N. (2011). Influence of Different Colored Plastic Mulch on the Growth of Lettuce (Lactuca sativa). Journal of Ornamental and Horticultural Plants. 1, 97-104. Retrieved from https://pdfs.semanticscholar.org/6d2b/95e5fc47112e17e4bbabbe29e63e6d400754.pdf.

Gee, G. W., \& Or B. D. (2002). Particle size analysis. In: J. H. dane and G. C. Topp (eds). Methods of soil analysis part, 4, 255-293. Retrieved from https://www.scirp.org/(S(i43dyn45teexjx455qlt3d2q))/reference/ReferencesPapers.aspx?ReferenceID=1612 861.

Hanada, T. (1991). The Effect of Mulching and Row Covers on Vegetable Production. Publication of Chugoku Agriculture Experimentation Station., Japan. 23. Retrieved from https://www.fftc.org.tw/htmlarea_file/library/20110801145616/eb332.pdf.

Ibarra-Jiménez, L., Quezada-Martín, M. R., \& Rosa-Ibarra, M. (2004). The effect of plastic mulch and row covers on the growth and physiology of cucumber. Australian Journal of Experimental Agriculture, 44, 91-94. https://www.researchgate.net/deref/http\%3A\%2F\%2Fdx.doi.org\%2F10.1071\%2FEA02088.

Ibeawuchi, I. I., Iheoma, O. R., Obilo O. P., \& Obiefuna, J. C. (2008). Effect of Time of Mulch Application on the Growth and Yield of Cucumber (Cucumis sativus) in Owerri, Southeastern Nigeria. Life Science Journal, 5(1), 68-71. Retrieved from http://www.lifesciencesite.com//sj/life0501/20_life0501_90_93_effect.pdf. 
Katan, J. (1981). Solar heating (solrization) of soil for control of soil- borne pests. Annual review of phytopathology, 78, 1215-1219. https://doi.org/10.1146/annurev.py.19.090181.001235.

Kuo, S. (1996). Phosphorus. In Sparks, D. L., (Ed.), Methods of Soil Analysis, Part 3, Chemical Methods, SSSA and ASA, Madison (pp. 869-920). Retrieved from https://www.scirp.org/(S(351jmbntvnsjt1 aadkposzje))/reference/ReferencesPapers.aspx?ReferenceID=1234 499.

Lamont, W. J. (2005). Plastics: Modifying the microclimate for the production of vegetable crops. HortTechnology, 15, 477-481. Retrieved from https://www.researchgate.net/publication/279888606.

Lamont, W. J. (2007). The use of different colored mulches for yield and earliness. Proceedings of the New England vegetable and berry growers conference and trade show, 122. Retrieved from https://www.sba.gov/page/disaster-loan-applications.

Liakatas, A. J., Clark, A., \& Monteith, J. L. (2005). Measurement of the heat balance under plastic mulches part 1. Radiation balance and soil heat flux. Agriculture for Meteorology, 36, 227-239. Retrieved from https://europepmc.org/article/agr/ind86039464.

Marinari, S., Mancinelli, R., Campiglia, E., \& Grego, S. (2006). Chemical and biological indicators of soil quality in organic and conventional farming systems in Central Italy. Ecological Indicators, 64, 701-711. Retrieved from https://www.researchgate.net/deref/http\%3A\%2F\%2Fdx.doi.org\%2F10.1016\%2Fj.ecolind.2005.08.029

Mutetwa, M., \& Mtaita, T. (2014). Effects of mulching and fertilizer sources on growth and yield of onion. Journal Global Innovative Agricultural Social Science, 2, 102-106. https://doi.org/10.17957/JGIASS/2.3.561 http://www.jgiass.com.

Nikolaeva, M. G., Ljanguzova, I. V., \& Pozdova, L. M. (2002). Biologija semjan Rossijskaja Akademija Nauk, Botanicheskij Institution, V.A Komarova Sanktpeterburg, Rossija, 232.

Shinomura, T., Nagatani, A., Hanzawa, H., Kubota, M., Watanabe, M., \& Furuya, M. (1996). Action spectra for phytochrome A- and phytochrome B-, specific photo-induction of seed germination in Arabidopsis thaliana. Plant Biology. Proc. Natl. Acad. Sci., 93, 8129-8133. Retrieved from https://www.pnas.org/content/93/15/8129.

Smolikowski, B., Piug, H., Roose, E. (2001). Influence of soil protection techniques on runoff, erosion and plant production on semi-arid hillsides of Cabo Verde. Agriculture, Ecosystems and Environment, 87, 67-80. Retrieved from https://www.sciencedirect.com/science/article/abs/pii/S0167880900002929.

Spear, J. F., Tekrony, D. M., \& Egli, D. B. (2005). Temperature during seed filling and soybean seed germination and vigour. Seed Science and Technology, 25, 233-24. Retrieved from http://agris.fao.org/agrissearch/search.do?recordID $=$ CH1997000338.

Walkley, A. C., \& Black, T. A. (1935). Estimation of soil organic carbon by chromic acid titration method. Soil Science, 47, 29-38. https://link.springer.com/article/10.1007/s40093-017-0179-1.

Watson, E. B., Wark, D. A., \& Thomas, J. B. (2006). Crystallization thermometers for zircon and rutile, Contribution Mineral Petrol, 151, 413-433. Retrieved from http://homepages.rpi.edu/home/61/watsoe/yesterday/public_html/research/Watson_etal_CMP06.pdf.

\section{Copyrights}

Copyright for this article is retained by the author(s), with first publication rights granted to the journal.

This is an open-access article distributed under the terms and conditions of the Creative Commons Attribution license (http://creativecommons.org/licenses/by/4.0/). 